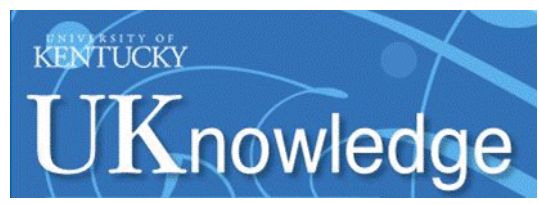

University of Kentucky

UKnowledge

\title{
Milk Production in Goats on Veld Hay Supplemented with Selected Legume Forages
}

Katsande Simbarashe

University of Venda, South Africa

Joseph J. Baloyi

University of Venda, South Africa

F. V. Nherera-Chokuda

Agriculture Research Centre Irene, South Africa

N. T. Ngongoni

Zimbabwe Open University, Zimbabwe

Follow this and additional works at: https://uknowledge.uky.edu/igc

Part of the Plant Sciences Commons, and the Soil Science Commons

This document is available at https://uknowledge.uky.edu/igc/23/2-1-1/1

The XXIII International Grassland Congress (Sustainable use of Grassland Resources for Forage Production, Biodiversity and Environmental Protection) took place in New Delhi, India from November 20 through November 24, 2015.

Proceedings Editors: M. M. Roy, D. R. Malaviya, V. K. Yadav, Tejveer Singh, R. P. Sah, D. Vijay, and A. Radhakrishna

Published by Range Management Society of India

This Event is brought to you for free and open access by the Plant and Soil Sciences at UKnowledge. It has been accepted for inclusion in International Grassland Congress Proceedings by an authorized administrator of UKnowledge. For more information, please contact UKnowledge@lsv.uky.edu. 
Paper ID: 41

Theme 2. Grassland production and utilization

Sub-theme 2.1. Quality, production, conservation and utilisation

\title{
Milk production in goats on veld hay supplemented with selected legume forages
}

\author{
Katsande Simbarashe $^{1 *}$, J. J. Baloyi ${ }^{1}$, F. V. Nherera-Chokuda ${ }^{2}$, N. T. Ngongoni ${ }^{3}$ \\ ${ }^{1}$ University of Venda, Thohoyandou, South Africa \\ ${ }^{2}$ Agriculture Research Centre Irene, Pretoria, South Africa \\ ${ }^{3}$ Zimbabwe Open University, Harare, Zimbabwe \\ *corresponding author e-mail : simbarashe46@gmail.com
}

Keywords: Forage legume supplements, Goats, Milk

\section{Introduction}

Alternative affordable sources of feed such as forage legumes that provide protein, vitamins and mineral elements, which are lacking in mature natural grassland pastures, especially during the dry season (Baloyi et al. 2008), can be an option. The high protein content of these legumes suggests that they have high potential for use as protein supplements in goat feeding. However, there is need for an in-depth study of the utilization of different legume forages for milk production in goats. Gusha et al. (2014) reported that supplementing with legume hays could improve poor quality roughage intake in goats. Snyman (2010) observed lower kid mortality in supplemented does compared to those not supplemented during lactation. Therefore, this research was designed to investigate the effects of supplementing Desmodium uncunatum, Mucuna pruriens and Vigna unguiculata forage legumes to low quality veld hay on milk production in indigenous goats.

\section{Materials and Methods}

The experiment was carried out at the University of Zimbabwe Animal Science. Sixteen (Mashona) indigenous lactating does $30 \pm 2 \mathrm{~kg}$ body weight $(20 \pm 10 \mathrm{~d}$ post-partum) in their third parity were used. Sixteen lactating goats were randomly allocated to 4 treatments consist of veld hay supplemented at $30 \%$ of 5\% body weight (BW) with (T1) commercial goat feed (CF); (T2) velvet bean (VB), (T3) silverleaf (SD) and (T4) cowpea (CW) with four replicates. Adaptation period of $14 \mathrm{~d}$ and $20 \mathrm{~d}$ for milk production and sample collection were allowed to the goats. Samples of diets and feed refusals were also obtained and composited for each period.

\section{Results and Discussion}

Daily feed intake on the treatment diets and hay was significantly highest in goats supplemented with goat feed followed by the goats on cowpea, velvet bean and silverleaf, respectively $(\mathrm{P}<0.05)$.Total DMI and ME intake were not different in all the diets $(\mathrm{P}>0.05)$. The dietary $\mathrm{ME}$ intake was highest in goats supplemented with velvet bean and silverleaf in comparison to the commercial goat feed and cowpea $(\mathrm{P}<0.05)$. Goats supplemented with cowpea had the highest crude protein intake followed by commercial goat feed, velvet bean and silverleaf correspondingly. Metabolisable protein intake and Metabolisable protein intake were not significantly different in all the treatments. Milk yield was significantly highest in goats supplemented with commercial goat feed followed by cowpea, silverleaf and velvet bean respectively $(\mathrm{P}<0.05)$. The fat, protein, lactose and ash in the milk were not different between the animals of the four treatments $(\mathrm{P}>0.05)$. Although, the goats were allowed ad libitum dry matter intake they did not respond to the high energy demand associated with milk yield by increasing dry matter intake. The DMI were not significantly different and this was also observed by Barnes et al. (1990). This may be due to the explanation by Blake and Custodio (1984) that increased milk yield and milk yield to feed intake ratio occurs only as long as tissue reserves are able to support the nutrient required for milk yield. The values obtained in this study on the efficient of utilization of feed by the goats for milk production are within the ranges obtained by other authors. Williams et al. (2012) reported efficiency of feed utilization for milk production of 0.237-0.431 in Wad goats. The efficient utilization of feed by the ruminants may possibly be accredited to the physiological status, breed of the animals and the quality of the ration offered.

\section{Conclusion}

The three selected legume forages used reflect that they can provide good quality forage for use as supplement to relatively low quality basal diets of veld hay on animals in the smallholder communal areas. Milk produced by these indigenous goats has unique characteristics (higher fat and protein content) making it better than the milk of specialized dairy goats. 


\section{References}

Baloyi, J. J., N. T. Ngongoni and H. Hamudikuwanda. 2008. Chemical composition and ruminal degradability of cowpea and Silverleaf desmodium forage legumes harvested at different stages of maturity. Tropical and Subtropical Agroecosystems 8: 81-91.

Gusha, J., C. R. Manyuchi, V. E. Imbayarwo-Chikosi, V. R. Hamandishe, S. Katsande and P. I. Zvinorova. 2014. Production and economic performance of F1-crossbred dairy cattle fed non-conventional protein supplements in Zimbabwe. Tropical animal Health and Production 46:229-234.

Snyman, M. A. 2010. Factors affecting pre-weaning kid mortality in South African Angora goats South African Journal of Animal Science 40 (1): 54-64.

Barnes, M. A., R. E. Pearson and A. J. Luke-Wilson. 1990. Effect of milking frequency and selection for milk yield on productive efficiency of Holstein cows. Journal of Dairy Science 73: 1603-1611.

Blake, R.W. and A. A. Custodio. 1984. Feed efficiency: a composite trait of dairy cattle. Journal of Dairy Science 67: 2075.

Williams, T. J., O. A. Osinowo, O. F. Smith, I. J. James, C. O. N. Ikeobi, O. M. Onagbesan, O. O. Shittu and F. T. Sololá. 2012. Effects of milking frequency on milk yield, dry matter intake and efficiency of feed utilization in Wad goats. Archiva Zootechinology 61 (235): 457-465.

\section{Acknowledgement}

Authors would like to thank the University of Venda for all the financial assistance and the University of Zimbabwe for providing the research animals and facilities. 